\title{
Effect of live Saccharomyces cerevisiae feeding on serum biochemistry in early weaned cross bred piglets
}

\author{
Sachin Kumar, A K Verma, S K Mondal, Mahesh Gupta, A K Patil, Babu Lal Jangir \\ Indian Veterinary Research Institute, \\ Izatnagar, Bareilly - 243 122, UP , India \\ Corresponding author: Sachin Kumar, email:arensachin@gmail.com \\ Received: 14-05-2012, Accepted: 22-05-2012, Published Online: 17-09-2012 \\ doi: 10.5455/vetworld.2012.663-666
}

\begin{abstract}
Aim: To assess the effect of feeding live Saccharomyces cerevisiae on serum biochemistry in early weaned cross bred (Landrace $\times$ Desi) piglets

Materials and Methods: 48 piglets assigned to four different groups (T1, T2, T3 and T4: $n=12$ ) following completely randomized design. T1 and T2 were weaned at age of 28 days while T3 and T4 were weaned at age of 42 days. T1 and T3 were fed basal diet without $S$. cerevisiae, however, T2 and T4 were supplemented with live $S$. cerevisiae $(200 \mathrm{~g} / \mathrm{d} / \mathrm{h}$ containing 2 $\left.3 \times 10^{6} \mathrm{cfu} / \mathrm{g}\right)$.

Results: The period-wise comparison of mean values of serum albumin and globulin were similar, however, period-wise comparison of protein was significant. The mean glucose value of T4 was statistically higher than T1 and comparable with $\mathrm{T} 2$ and T3. The serum total cholesterol level was found to be lower in T2 and T4 as compared to T1 and T3.

Conclusion: Results of study suggest that supplementation of live Saccharomyces cerevisiae was effective in improving the health status of early weaned piglets.

Keywords: early weaned piglets, Saccharomyces cerevisiae, serum biochemistry
\end{abstract}

To cite this article: Kumar S, Verma AK, Mondal SK, Gupta M, Patil AK, Jangir BL (2012) Effect of live Saccharomyces cerevisiae feeding on serum biochemistry in early weaned cross bred piglets, Vet World, 5(11): 663-666, doi: 10.5455/vetworld.2012.663-666

\section{I ntroduction}

Early weaning increase the potential for annual production of piglets per sow and profit of farmer. Weaning is a complex process. At the time of weaning, young piglets are subjected to several stressors such as nutritional, environmental, psychological, social and microbial imbalance resulted in to low feed intake, impaired intestinal morphology and function [1]. Antibiotics have traditionally been widely used in nursery pigs to solve post weaning problems [2]. However, there is an increasing evidence of microorganisms becoming resistant to antibiotics in both animal and human [3]. Feeding of probiotics in piglets came up as an alternative of antibiotics. The best indicator of animal's well being and its potential for production is its health status. Madubuike and Ekenyem [4] had stated that haematology and serum biochemistry assay of livestock suggests the physiological disposition of the animals to their nutrition.
Serum biochemistry is important indicator of health and disease in animals and has become indispensible in the diagnosis, treatment or prognosis of many diseases [5]. Deter-mination of the serum biochemistry reflects the physiological responsiveness of the animals to its internal and external environment [6].

Keeping above in view, the present study was conducted to assess the effect of feeding live Saccharomyces cerevisiae on serum biochemistry in early weaned cross bred (Landrace $\times$ Desi) piglets.

\section{Materials and Methods}

Ethical approval: Prior approval for experiments was taken from Institutional Animal Ethics Committee as per CPCSEA(Govt. of India) norms.

A total of 48 crossbred piglets weaned at 28 and 42 days were selected for the present study and were assigned to four different groups (T1, T2, T3 and T4) of 12 piglets in each group. T1 and T2 group piglets were weaned at 28 days of age and $\mathrm{T} 3$ and $\mathrm{T} 4$ group 
Table-1. Physical composition of ration for piglets

\begin{tabular}{lllll}
\hline Ingredients (Parts/100 Kg) & $\mathbf{5 - 1 0}$ & $\begin{array}{l}\text { Body weights } \mathbf{( k g )} \\
\mathbf{1 0 - 2 0}\end{array}$ & $\mathbf{2 0 - 5 0}$ & $\mathbf{5 0 - 8 0}$ \\
\hline Crushed maize & 46 & 54 & 62 & 71 \\
Deoiled soya bean meal & 30 & 22 & 15 & 10 \\
Wheat bran & 16 & 16 & 15 & 13 \\
Fish meal & 06 & 06 & 06 & 04 \\
Mineral mixture & 1.5 & 1.5 & 1.5 & 1.5 \\
Common salt & 0.5 & 0.5 & 0.5 & 0.5 \\
Calculated CP (\%) & 23.7 & 20.9 & 18.3 & 15.6 \\
Calculated DE (kcal/kg) & 3400.1 & 3399.45 & 3399.37 & 3390 \\
\hline
\end{tabular}

piglets were weaned at 42 days of age. T1 and T3 groups were fed basal diet without $S$. cerevisiae while T2 and T4 were fed basal diet supplemented with live S. cerevisiae. Basal diet was formulated with maize, soyabean meal, fish meal, wheat bran, salt, mineral mixture and vitamin supplements as per NRC [7]. Physical composition of the diet was as given in (Table 1.) Crushed maize was fermented with $S$. cerevisiae $\left(2-3 \times 10^{6} \mathrm{cfu} / \mathrm{g}\right.$ feed) as described below and fed @ $200 \mathrm{~g}$ (on fresh basis) per piglet per day to T2 and T4 groups. The study was continued for 120 days. Blood was collected at 0 and 120 days of experimental trial and serum was collected and then stored at $-20^{\circ} \mathrm{C}$ until it analysis. Finally after thawing, serum was analyzed for various biochemical and enzymatic profiles by standard protocol as per kit (Span Diagnostics Ltd. Surat, India) using spectrophotometer.

Fermentation of maize with S. verevisiae culture: The $S$. cerevisiae (yeast) culture was maintained by repeated sub culturing on agar slants. The ingredients of yeast extract peptone glucose (YEPG) medium (composition/1000ml) were yeast extract-3 g, Peptone-5 g, Glucose-10 g, Agar-15 g and distilled water-1 lit.

Preparation of yeast culture for feeding: From the agar slant of yeast, a loopful of yeast culture was transferred aseptically to $100 \mathrm{ml}$ of sterilized broth (Table 2). The broth was incubated for 24 hours at $39^{\circ} \mathrm{C}$. Crushed maize $(1000 \mathrm{~g})$ mixed with $1000 \mathrm{ml}$ of tap water was inoculated with the $100 \mathrm{ml}$ of 24 hours old yeast culture (10\% of the total feed) and incubated for 24 hours at $39^{\circ} \mathrm{C}$. The fermented material was fed to the animals and the same fermented material was used as inoculum (20\% of concentrate mixture) for preparation of next day's fermented feed. After 15 days, fresh culture was taken as described above and used consecutively for next 15 days.

Statistical Analysis: The experimental data generated were analyzed using the statistical software program SPSS (SPSS Inc., Chicago, Illinois, USA).
Table-2. Composition of medium for growing Saccharomyces cerevisiae

\begin{tabular}{lc}
\hline Ingredients & Composition/1000ml \\
\hline Yeast extract & $3 \mathrm{~g}$ \\
Peptone & $5 \mathrm{~g}$ \\
Glucose & $10 \mathrm{~g}$ \\
Distilled water & Up to $1000 \mathrm{ml}$ \\
\hline
\end{tabular}

\section{Results and Discussion}

The results are presented in Table-3. The plasma protein concentration at any given time is in turn a function of hormonal balance, nutritional status, water balance and other factors affecting the state of health. In the present study, serum total proteins, albumin and globulin remained within normal range [8] and did not differ significantly among different dietary treatments. The period-wise comparison of mean values of serum albumin and globulin were similar, however, periodwise comparison of serum protein was statistically significant. This may be due to improvement in appetite and feed utilization by the animals. Our results were paralleled with that recorded by Bakr et al. [9] who reported no significant difference in the levels of serum albumin and globulin in probiotic treated calves, however, they observed a significant increase in the levels of serum total proteins. The findings were also in harmony with that recorded by Sayed [10] in probiotic treated kid. Chen et al. [11] concluded that there was no effect of complex probiotic feeding on total protein and albumin. The activities of glucose in the present investigation were significantly changed along the period of the experiments. The present findings were line with the observation of Bakr et al. [9]. Serum glucose values also increased both in T2 and T4 due to supplementation of $S$. cerevisiae as compared to their respective control, though the difference was not significant. The serum glucose level of T4 was significantly higher in as compared to T1. Significant increased in serum glucose levels in probiotic treated buffalo calves was observed by Bakr et al. [9]. The level of cholesterol was significantly 
Effect of live Saccharomyces cerevisiae feeding on serum biochemistry in early weaned cross bred piglets

Table-3. Effect of different treatments on Serum biochemical profile

\begin{tabular}{|c|c|c|c|c|}
\hline Attributes & Treatment & $\mathbf{O d}$ & $120 \mathrm{~d}$ & Mean \\
\hline Total Protein & $\begin{array}{l}\text { T1 } \\
\text { T2 } \\
\text { T3 } \\
\text { T4 } \\
\text { Mean }\end{array}$ & $\begin{array}{l}6.4 \pm 0.20 \\
6.5 \pm 0.20 \\
6.6 \pm 0.17 \\
6.6 \pm 0.12 \\
6.5 \pm 0.08^{b}\end{array}$ & $\begin{array}{l}6.6 \pm 0.15 \\
7.1 \pm 0.19 \\
6.7 \pm 0.15 \\
7.1 \pm 0.11 \\
6.9 \pm 0.08^{a}\end{array}$ & $\begin{array}{l}6.5 \pm 0.13 \\
6.8 \pm 0.15 \\
6.6 \pm 0.11 \\
6.9 \pm 0.10\end{array}$ \\
\hline Albumin & $\begin{array}{l}\text { T1 } \\
\text { T2 } \\
\text { T3 } \\
\text { T4 } \\
\text { Mean }\end{array}$ & $\begin{array}{l}3.8 \pm 0.11 \\
3.7 \pm 0.08 \\
3.9 \pm 0.15 \\
4.1 \pm 0.22 \\
3.9 \pm 0.07\end{array}$ & $\begin{array}{l}4.0 \pm 0.21 \\
3.9 \pm 0.13 \\
4.0 \pm 0.13 \\
4.0 \pm 0.23 \\
4.0 \pm 0.09\end{array}$ & $\begin{array}{l}3.9 \pm 0.12 \\
3.8 \pm 0.08 \\
4.0 \pm 0.10 \\
4.1 \pm 0.15\end{array}$ \\
\hline Globulin & $\begin{array}{l}\text { T1 } \\
\text { T2 } \\
\text { T3 } \\
\text { T4 } \\
\text { Mean }\end{array}$ & $\begin{array}{l}2.6 \pm 0.18 \\
2.7 \pm 0.26 \\
2.6 \pm 0.17 \\
2.5 \pm 0.28 \\
2.6 \pm 0.11^{b}\end{array}$ & $\begin{array}{l}2.7 \pm 0.18 \\
3.2 \pm 0.12 \\
2.7 \pm 0.12 \\
3.1 \pm 0.25 \\
2.9 \pm 0.10^{\mathrm{a}}\end{array}$ & $\begin{array}{l}2.6 \pm 0.12 \\
2.9 \pm 0.15 \\
2.7 \pm 0.10 \\
2.8 \pm 0.20\end{array}$ \\
\hline Glucose & $\begin{array}{l}\text { T1 } \\
\text { T2 } \\
\text { T3 } \\
\text { T4 } \\
\text { Mean }\end{array}$ & $\begin{array}{l}95.9 \pm 2.83 \\
96.0 \pm 1.20 \\
99.7 \pm 3.24 \\
99.0 \pm 1.46 \\
97.6 \pm 1.16^{b}\end{array}$ & $\begin{array}{l}101.7 \pm 1.52 \\
111.5 \pm 0.83 \\
106.5 \pm 2.19 \\
116.0 \pm 0.99 \\
108.9 \pm 1.19^{a}\end{array}$ & $\begin{array}{l}98.8 \pm 1.72^{\mathrm{b}} \\
103.8 \pm 2.13^{\mathrm{ab}} \\
103.1 \pm 2.09^{\mathrm{ab}} \\
107.5 \pm 2.35^{\mathrm{a}}\end{array}$ \\
\hline Cholesterol & $\begin{array}{l}\text { T1 } \\
\text { T2 } \\
\text { T3 } \\
\text { T4 } \\
\text { Mean }\end{array}$ & $\begin{array}{l}54.6 \pm 2.87 \\
47.4 \pm 0.52 \\
54.3 \pm 2.26 \\
47.9 \pm 1.61 \\
51.0 \pm 1.14\end{array}$ & $\begin{array}{l}52.3 \pm 2.91 \\
45.4 \pm 1.57 \\
53.2 \pm 2.47 \\
46.4 \pm 1.94 \\
49.3 \pm 1.25\end{array}$ & $\begin{array}{l}53.4 \pm 2.00^{\mathrm{a}} \\
46.4 \pm 0.84^{\mathrm{b}} \\
53.8 \pm 1.62^{\mathrm{a}} \\
47.1 \pm 1.23^{\mathrm{b}}\end{array}$ \\
\hline Triglycerides & $\begin{array}{l}\text { T1 } \\
\text { T2 } \\
\text { T3 } \\
\text { T4 } \\
\text { Mean }\end{array}$ & $\begin{array}{l}28.9 \pm 1.64 \\
29.3 \pm 1.56 \\
29.3 \pm 1.31 \\
28.9 \pm 1.64 \\
29.1 \pm 0.74\end{array}$ & $\begin{array}{l}34.0 \pm 2.16 \\
30.9 \pm 1.81 \\
34.0 \pm 1.09 \\
30.9 \pm 1.91 \\
32.4 \pm 0.90\end{array}$ & $\begin{array}{l}31.4 \pm 1.47 \\
30.1 \pm 1.17 \\
31.6 \pm 1.02 \\
29.9 \pm 1.24\end{array}$ \\
\hline Serum urea & $\begin{array}{l}\text { T1 } \\
\text { T2 } \\
\text { T3 } \\
\text { T4 } \\
\text { Mean }\end{array}$ & $\begin{array}{l}22.5 \pm 0.56 \\
22.2 \pm 0.35 \\
22.6 \pm 0.47 \\
22.1 \pm 0.26 \\
22.3 \pm 0.20\end{array}$ & $\begin{array}{l}22.5 \pm .52 \\
22.2 \pm 0.34 \\
22.8 \pm 0.44 \\
22.2 \pm 0.31 \\
22.4 \pm 0.20\end{array}$ & $\begin{array}{l}22.5 \pm 0.37 \\
22.2 \pm 0.24 \\
22.7 \pm 0.31 \\
22.1 \pm 0.19\end{array}$ \\
\hline AST & $\begin{array}{l}\text { T1 } \\
\text { T2 } \\
\text { T3 } \\
\text { T4 } \\
\text { Mean }\end{array}$ & $\begin{array}{l}84.1 \pm 2.59 \\
85.6 \pm 1.80 \\
85.4 \pm 1.69 \\
85.3 \pm 3.00 \\
85.1 \pm 1.12\end{array}$ & $\begin{array}{l}86.2 \pm 1.64 \\
84.9 \pm 5.00 \\
85.6 \pm 3.33 \\
84.0 \pm 3.43 \\
85.2 \pm 1.69\end{array}$ & $\begin{array}{l}85.2 \pm 1.50 \\
85.3 \pm 2.57 \\
85.5 \pm 1.80 \\
84.6 \pm 2.21\end{array}$ \\
\hline ALT & $\begin{array}{l}\text { T1 } \\
\text { T2 } \\
\text { T3 } \\
\text { T4 } \\
\text { Mean }\end{array}$ & $\begin{array}{l}40.0 \pm 3.85 \\
39.7 \pm 3.42 \\
39.7 \pm 2.82 \\
40.2 \pm 3.28 \\
39.9 \pm 1.60\end{array}$ & $\begin{array}{l}43.8 \pm 2.21 \\
41.8 \pm 2.28 \\
43.4 \pm 2.78 \\
42.2 \pm 2.95 \\
42.8 \pm 1.23\end{array}$ & $\begin{array}{l}41.9 \pm 2.20 \\
40.7 \pm 2.00 \\
41.5 \pm 1.97 \\
41.2 \pm 2.15\end{array}$ \\
\hline
\end{tabular}

abc-Means bearing different superscripts in a row differ significantly $(P<0.05)$

decreased in yeast fed piglets as compared to control.

The values of triglycerides were also lower but not statistically significant. The present findings were in agreement with Jouybari et al. [12], Ahmadi [13] and Oie [14] who have observed the low levels of cholesterol synthesis in chickens treated with probiotics. Homayouni et al. [15] did conclude the same result in a review.

The beneficial effect of $S$. cerevisiae is attributed to the fact that it is a naturally rich source of enzymes, proteins, minerals and B-complex vitamins [16]. Yeast culture, and its cell wall extract containing 1,3-1,6 Dglucan and mannanoligosaccharide, are the important natural growth promoters for modern livestock. $S$. cerevisiae is considered as one of the most popular probiotic that, when administered through the digestive tract, have a positive impact on the host's health through its direct nutritional effect [17].

Probiotics have the ability to deconjugate with bile acids, enzymatically increasing their rate of excretion and the use of cholesterol to synthesize new bile lead to the reduction of serum cholesterol level [18]. Serum urea level was within the normal physiological range [8] and there was no effect of $S$. cerevisiae feeding. The obtained results were in consistent with that reported by Sayed [10]. The values of both ALT and AST were within the normal physiological range [8] and no significant difference was evident in growing pigs irrespective of dietary treatments. The levels of ALT and AST were 
insignificantly changed along the period of the experiment. The findings were in agreement with that detected by Patrascanu et al., [19] who reported that the activities of AST and ALT were normal and were similar in control and probiotic treated animals.

\section{Conclusion}

It can be concluded from present study that supplementation of live $S$. cerevisiae has obvious and beneficial effect on the serum biochemistry profile of the piglets and it was effective in improving the health status of early weaned piglets.

\section{Author's contribution}

SK, AKV and SKM designed the study. SK, MG, AKP and BLJ analyzed the samples. SK and AKV analyzed the data. SK and BLJ drafted the manuscript. All authors read and approved the final manuscript.

\section{Acknowledgements}

Authors sincerely thank to The Director, IVRI, Incharge pig farm, Head of Animal Nutrition Division, ICAR for facilities provided and financial support.

\section{Competing interests}

The authors declare that they have no competing interests.

\section{References}

1. Lalles, J.P. (2008). Nutrition and gut health of the young pig around weaning: what news? Archiva Zootechnica, 11:1, 5-15.

2. Kong, X.F., Yin, F.G., He, Q.H., Liu, H.J. and Li, T.J. (2009). Acanthopanax senticosus extract as a dietary additive enhances the apparent ileal digestibility of amino acid in weaned piglets. Livestock Science, 123: 261-267.

3. Cohen, M.L. (1992). Epidemology of drug resistance: implications for a post-antimicrobial era. Science, 257: 1050-1055.

4. Madubuike, F.N. and Ekenyem, B.U. (2006). Haematology and Serum Biochemistry characteristics of broiler chicks fed varying dietary levels of Ipomoea asarifolia Leaf Meal. International Journal of Poultry Science, 5: 09-12.

5. Eze, J.I., Onunkwo, J.I., Shoyinka, S.V.O., Chah, F.K., Ngene, A.A., Okolinta, N., Nwanta, J.A. and Onyenwe, I.W. (2010). Profiles of pigs raised under intensive management system in south-eastern Nigeria, Nigerian Veterinary Journal, 31(2): 115-123.

6. Esonu, B.O., Enenalom, O.O., Udedibie, A.B.I., Herbert, U., Ekpor, C.F., Okoli, I.C. and Iheukwumere, F.C. (2001). Performance and blood chemistry of weaner pigs fed raw mucuna (velvef bean) meal. Trop. Anim. Prod. Invest., 4: 49-55.

7. NRC. (1998). Nutrient Requirements of Swine. 10th Revised edition, National Academy Press, Washington, DC.

8. Kaneko, J.J., Harvey, J.W. and Bruss, M.L. (1997). Clinical Biochemistry of Domestic Animals, 5th Edn., Academy Press, San Diego, California, USA. pp 890894.

9. Bakr, H.A., Said, E.M., Abd El-Tawab, M.M. and Hassan, M.S. (2009). The impact of probiotic (Biovet $^{\Phi}$ ) on some clinical, haematological and biochemical parameters in buffalo calves. Beni-Suef Veterinary Medical journal, 19(1): 1-10.

10. Sayed, A.S. (2003). Studies on the influence of pronifer as a probiotics on the clinical, hematological and biochemical status of the goat' kids. Assiut Veterinary Medical Journal, 99(98): 131-143.

11. Chen, Y.J., Son, K.S., Min, B.J., Cho, J.H., Kwon, O.S. and Kim, I.H. (2005). Effects of dietary probiotic on growth performance, nutrients digestibility, blood characteristics and fecal noxious gas content in growing pigs. Asian Australian Journal of Animal Science, 18(10): 1464-1468.

12. Jouybari, M.G., Malbobi, M.A., Irani, M. and Pour, V.R. (2010). The effect of novel probiotic on performance and serum concentrations of cholesterol and triglyceride in broiler chickens. African Journal of Biotechnology, 9(45): 7771-7774.

13. Ahmadi, F. (2011). The effects of Saccharomyces cerevisiae (Thepax) on performance, blood parameters and relative weight of lymphoid organs of broiler chicks. Global Veterinaria, 6(5): 471-475.

14. Oie, L. and Liong, M. (2010). Cholesterol lowering effects of probiotics and probiotics: A review of in vivo and in vitro findings, International Journal of Molecular Science, 11(6): 2499-2522.

15. Homayouni, A., Payahoo, L. and Azizi, A. (2012). Effects of probiotics on lipid profile: A review. American Journal of Food Technology, 7 (5): 251256.

16. Shareef, A.M. and Al-Dabbagh, A.S.A. (2009). Effect of probiotics (Saccharomyces cerevisiae) on performance of broiler chicks. Iraqi Journal of Veterinary Sciences, 23: 23-29.

17. Patterson, J.A. and Burkholder, K.M. (2003). Application of prebiotics and probiotics in poultry production. Poultry Science; 82: 627-631.

18. Lye, H.S., Kuan, C.Y., Ewe, J.A., Fung, W.Y. and Liong, M.T. (2009). The improvement of hypertension by probiotics: Effects on cholesterol, diabetes, renin and phytoestrogens. International Journal of Molecular Science, 10:3755-3775.

19. Patrascanu, M.E., Radoi, I. and Vlagioiu, C. (2010). The effects of probiotics on performance and metabolism in swine - Scientific Works Veterinary Medicine Bucharest, C Series LV. 